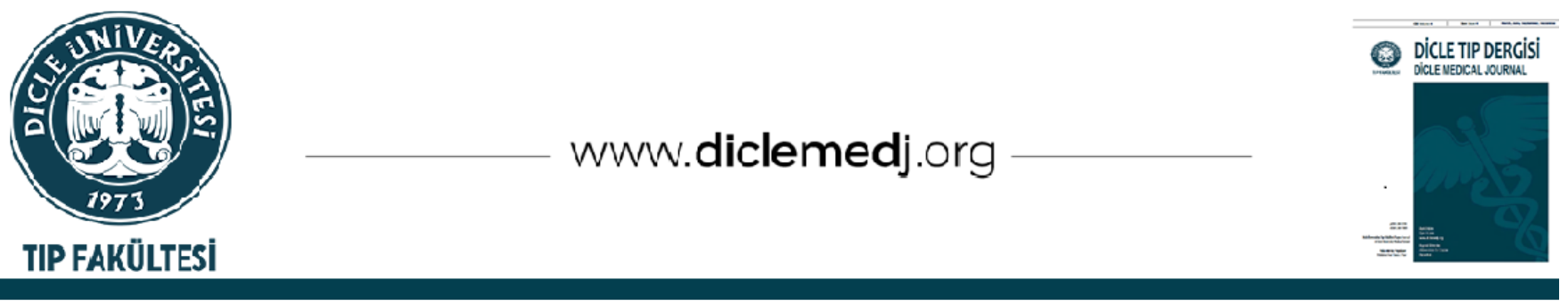

Original Article / Özgün Araştırma

\title{
Association of Fragmented QRS Morphology With Risk of Atrial Fibrillation in Hemodialysis Patients
}

\author{
Ekrem Aksu ${ }^{1}$, Abdullah Sokmen ${ }^{\text {1 }}$, Gulizar Sokmen ${ }^{1}$, Fatma Betul Guzel ${ }^{2}$, Adem Doganer ${ }_{3}$, \\ Ozkan Gungor ${ }^{\text {iD }} 4$ \\ 1 Department of Cardiology, Kahramanmars Sutcu Imam University, Faculty of Medicine, Kahramanmaras, Turkey \\ 2 Department of Internal Medicine, Kahramanmars Sutcu Imam University, Faculty of Medicine, Kahramanmaras, Turkey \\ 3 Department of Bioistatistics, Kahramanmars Sutcu Imam University, Faculty of Medicine, Kahramanmaras, Turkey \\ 4 Department of Nephrology, Kahramanmars Sutcu Imam University, Faculty of Medicine, Kahramanmaras, Turkey
}

Received: 02.07.2020; Revised: 02.12.2020; Accepted: 03.12.2020

\begin{abstract}
Objective: Atrial fibrillation (AF) is the most common form of arrhythmia in hemodialysis (HD) patients. Fragmented QRS (fQRS) morphology has been proposed as an ECG marker to predict the risk of paroxysmal AF in various conditions. In this study, we aimed to investigate the association between risk of AF development and P dispersion (Pd) and fQRS morphology in HD patients.
\end{abstract}

Methods: After analyzing the 24-hour Holter recordings of the patients, they were divided into 3 groups as without atrial runs (WAR), short atrial runs (SAR), and silent paroxysmal atrial fibrillation episode (SPAFE). In ECGs taken before HD, the presence of fQRS morphology was investigated, and Pd was measured.

Results: As a result of the analysis of the 24-hour Holter ECG recordings, it was determined that 12 of the 74 patients had SAR, while 6 had SPAFE. The duration of hemodialysis was significantly longer in the SPAFE groups than the WAR group ( $\mathrm{p}=0.026)$. It was found that fQRS morphology could be an independent predictor of SAR (odds ratio $=0.056$; 95\% CI, 0.006-0.548; $\mathrm{p}=0.013)$. The incidence of fQRS morphology was significantly higher in the SPAFE group than the WAR group ( $\mathrm{p}=0.002)$. However, this significance did not continue in the multivariate analysis. Pd was similar between the groups.

Conclusion: This retrospective study is the first study that investigated the association of fQRS morphology with SAR and SPAFE in HD patients, and it showed that fQRS morphology may be useful in distinguishing HD patients with a high AF risk.

Key words: Atrial fibrillation; fragmented QRS; hemodialysis; P dispersion

DOI: 10.5798/dicletip.850226

Correspondence / Yazışma Adresi: Ekrem Aksu, Kahramanmaras Sutcu Imam University, Faculty of Medicine, Department of Cardiology, Kahramanmaras, Turkey e-mail: drekremaksu4676@gmail.com 


\section{Hemodiyaliz Hastalarında Fragmente QRS Morfolojisinin Atriyal Fibrilasyon Riskiyle İlişkisi}

Öz

Amaç: Atriyal fibrilasyon (AF), hemodiyaliz (HD) hastalarında en sık görülen aritmi şeklidir. Çesitli durumlarda paroksismal AF riskinin tahmininde bir elektrokardiyografi (EKG) belirteci olan fragmente QRS (fQRS) morfolojisi önerilmiştir. Bu çalışmada HD hastalarında AF gelişme riski ile P dispersiyonu (Pd) ve fQRS morfolojisi arasındaki ilişkinin araştırılması amaçlanmıştır.

Yöntemler: Hastalar 24 saatlik holter kayıtları inceledikten sonra çalışma grubu atriyal atak olmayan (WAR), kısa atriyal atak (SAR) ve sessiz paroksismal atriyal fibrilasyon epizod olan (SPAFE) olmak üzere 3 gruba ayrıldı. HD'den önce alınan EKG'lerde fQRS morfolojisinin varlığı araştırıldı ve Pd ölçüldü.

Bulgular: Hastaların 24 saatlik Holter EKG kayıtlarının analizi sonucunda 74 hastanın 12'sinde SAR, 6'sında SPAFE saptandı. Hemodiyaliz süresi SPAFE gruplarında WAR grubuna göre anlamlı derecede daha uzundu $(p=0.026)$. fQRS morfolojisinin SAR için bağımsız bir prediktör olabileceği bulunmuştur (olasıllı oranı = 0.056;\% 95 GA, 0.006-0.548; $p=$ 0.013). fQRS morfolojisi insidansı SPAFE grubunda WAR grubuna göre anlamlı olarak yüksekti $(\mathrm{p}=0.002)$. Ancak, bu önem çok değişkenli analizde devam etmemiştir. Pd gruplar arasında benzerdi.

Sonuç: Bu retrospektif çalışma, HD hastalarında fQRS morfolojisinin SAR ve SPAFE ile ilişkisini araştıran ilk çalışmadır ve fQRS morfolojisinin AF riski yüksek olan HD hastalarını ayırt etmede yararlı olabileceğini göstermiştir.

Anahrar kelimeler: Atriyal fibrilasyon; fragmente QRS; hemodiyaliz; P dispersiyonu

\section{INTRODUCTION}

Arrhythmias are the leading cause of cardiovascular mortality in hemodialysis (HD) patients. Atrial fibrillation (AF) is the most common arrhythmia in HD patients and is $2-3$ times more common than the general population $^{1,2}$. AF is an arrhythmia that plays a role in the development of complications such as stroke, thromboembolism, and congestive heart failure ${ }^{3,4}$. It is important to differentiate HD patients with a high risk of developing this arrhythmia associated with increased cardiovascular mortality and morbidity ${ }^{1,5}$. Short atrial runs (SAR) and silent paroxysmal atrial fibrillation episode (SPAFE), which are determined in rhythm Holter recordings, are two different conditions associated with increased AF risk ${ }^{6-8}$. Atrium-related markers such as $\mathrm{P}$ wave duration (P) and $\mathrm{P}$ dispersion (Pd) were used while investigating ECG markers that could predict the development of $\mathrm{AF}^{9}$. However, in recent studies, it was reported that fragmented QRS (fQRS) morphology, which is accepted as an indicator of myocardial fibrosis, heterogeneous depolarization and chronic ischemia, may be a predictor of $\mathrm{AF}^{10-14}$. To the best of our knowledge, there is a lack of literature on the relationship of atrial and ventricular ECG markers and fQRS with the risk of developing AF in HD patients. In this study, we examined the relationship between AF risk in HD patients and Pd and fQRS morphology.

\section{METHODS}

\section{Patient selection}

This study was planned as a retrospective study. Patients who were diagnosed with chronic kidney failure and had hemodialysis treatment between January 2018 and July 2019 in the Nephrology clinic of our hospital and who had working conditions were included. The exclusion criteria were age under 18 years, congestive heart failure, moderate-severe valvular heart diseases, cardiac arrhythmias, permanent pacemaker implantation, antiarrhythmic medication use, bundle branch block on ECG, hyper- or hypothyroidism, and autoimmune diseases. A total of 74 patients 
with twelve-lead ECG samples taken after hemodialysis at $25 \mathrm{~mm} / \mathrm{sec}$ velocity on a standard ECG paper with $0.16-100 \mathrm{~Hz}$ filter range and $10 \mathrm{~mm} / \mathrm{mV}$ voltage were included in the study. Demographic and laboratory data, standard echocardiography reports, and 24hour Holter ECG recordings of these patients were obtained from archive records.

\section{Electrocardiography}

The 12-lead ECG recordings taken after hemodialysis were evaluated by two cardiologists blinded to the study data. The presence of RSR waves or and notching at the lowest point of the $\mathrm{R}$ wave or $\mathrm{S}$ wave in at least two adjacent leads compatible with the main coronary artery region in the ECG sample without bundle branch block was defined as QRS fragmentation (Figure 1) ${ }^{15}$. $\mathrm{P}$ wave duration in all derivations was calculated. Maximum (Pmax) and minimum (Pmin) P wave durations were calculated. $P$ dispersion (Pdis) was defined as the difference between Pmax and Pmin.

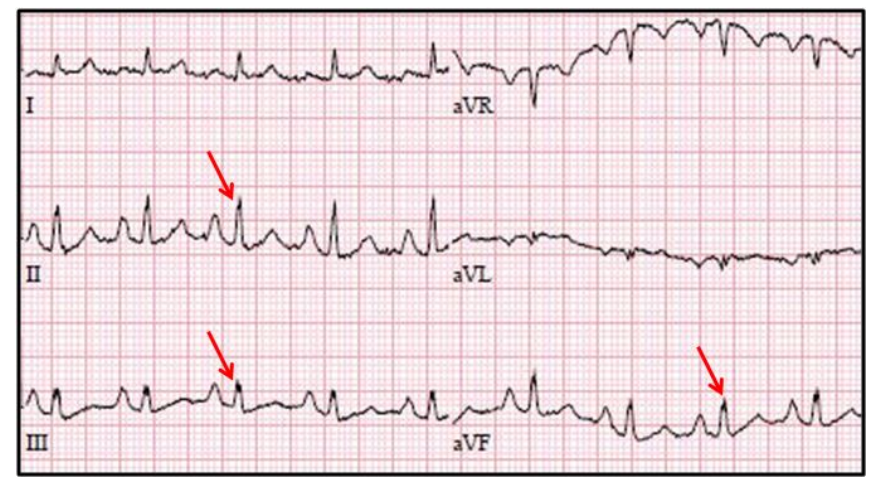

Figure 1. ECG sample demonstrating fragmentation of QRS in inferior derivations

\section{Holter ECG}

The Holter recordings of all patients were taken in 1-day intervals, on the day between two consecutive dialysis sessions. 24-hour Holter ECG recordings (Walk 400h Cardioline, Milan, Italy) were analyzed was accepted as statistically significant. IBM SPSS Statistics for Windows version 22 (IBM SPSS for Windows version 22, IBM Corporation, Armonk, by 2 experienced cardiologists who were blind to the patient data. Supraventricular runs presenting as irregular RR intervals without a distinct $\mathrm{P}$ wave were accepted as SAR if they consisted of at least 3 consecutive beats lasting $<30 \mathrm{~s}$, and accepted as SPAFE if they lasted $>30 \mathrm{~s}$. The 'without atrial runs' (WAR) group consisted of patients in whom no atrial runs consisting of at least 3 consecutive beats in an irregular character could be detected.

\section{Echocardiography}

Standard transthoracic echocardiography reports of the patients were obtained using the Vivid $7 \AA$ cardiac ultrasonography device (GE VingMed Ultrasound AS; Horten, Norway) with a $2.5-5-\mathrm{MHz}$ probe available in the clinic. M-mode, twodimensional, and color-Doppler echocardiographic findings were examined. Left ventricular (LV) measurements, left atrium and aortic root measurements were made using the M-mode method from the parasternal long-axis window. The left ventricular ejection fraction (LVEF) was measured using the Teichholz formula. Mitral early diastolic (E), and late diastolic (A) velocities were measured with pulsed wave Doppler (PW) during diastole by placing sample volume to the tips of mitral leaflets, and $\mathrm{E} / \mathrm{A}$ ratio was calculated.

The research protocol in line with the Helsinki Declaration was approved by the local ethics committee (Approval Date: 05.05.2019; Protocol No:2019/09/02).

\section{Statistical Analysis}

The compliance of the variables with normal distribution was examined by the Shapiro-Wilk test. Kruskal Wallis $\mathrm{H}$ test was used for the non-normally distributed variables. Dunn-Sidak test was applied as a post hoc test. Chi-squared tests and Exact tests were used to examine the distribution of the categorical variables. Multinomial Logistic Regression analysis was applied in determining the predictive value of the variables. The statistical parameters are expressed as Median (25\% quartile$75 \%$ quartile), frequency ( $\mathrm{n}$ ) and ratio (\%).p $<0.05$

New York, United States) was utilized to analyze the data. 


\section{RESULTS}

According to the results of the analysis of the 24hour Holter ECG recordings, 12 of the 74 patients had SAR, while 6 had SPAFE. The sample of the study was divided into three groups as WAR, SAR, and SPAFE. Demographic data were similar between groups. Moreover, the prevalence of coronary artery disease was significantly higher in the WAR group $(\mathrm{p}=0.012)$ (Table I). The dialysis duration was significantly longer in the SPAFE group than the WAR group $(\mathrm{p}=0.026)$. The serum potassium levels were significantly lower in the SAR group than the WAR and SPAFE groups $(\mathrm{p}=0.049)$. Other laboratory parameters were similar among the groups (Table I).

Tablo I: Demographic features and laboratory findings of the groups

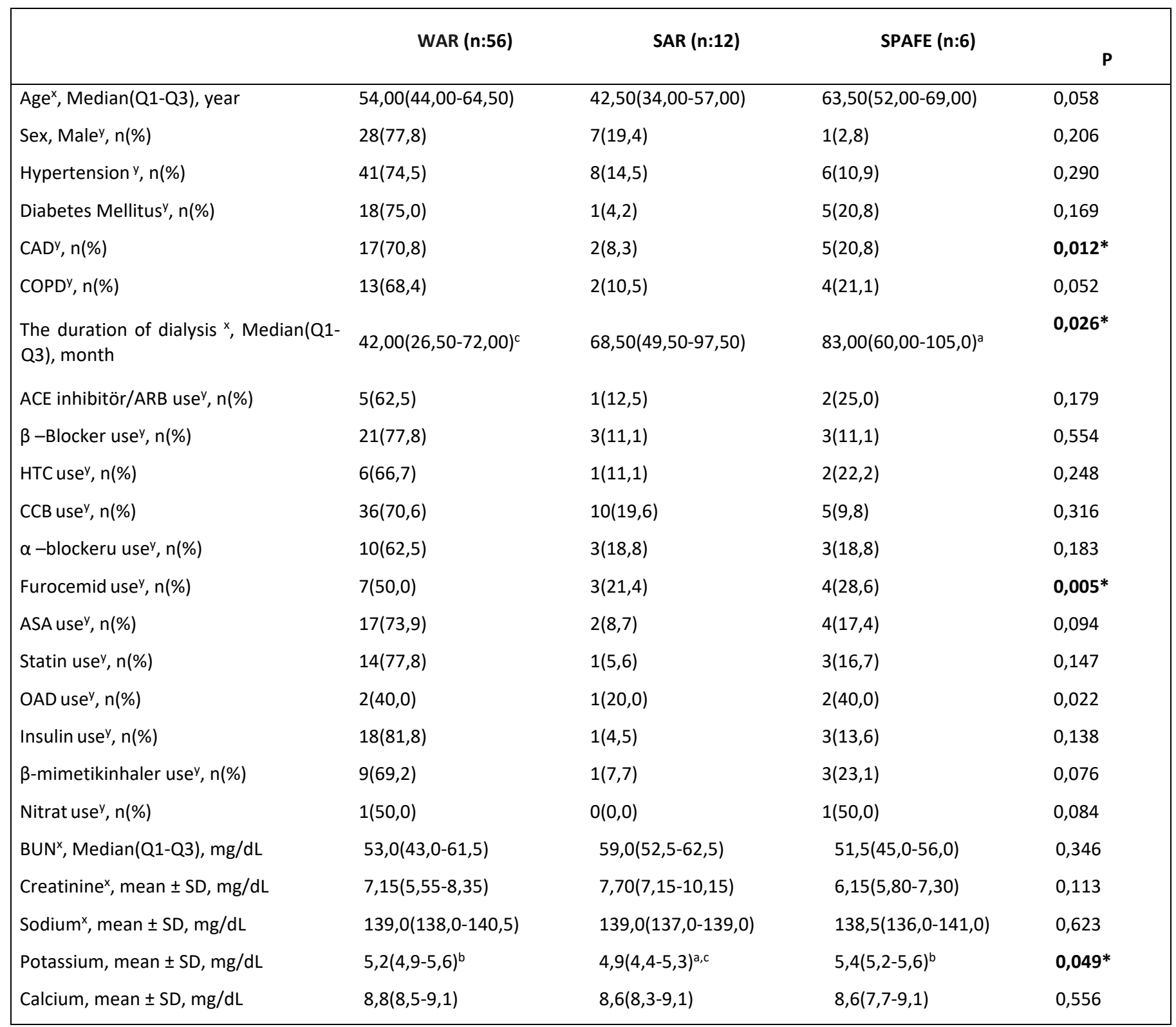

CAD; Coronary artery disease, COPD; Chronic obstructive pulmonary disease, ACE; angiotensin-converting enzyme, ARB; Angiotensin receptor blocker, CCB;calcium channel blocker, ASA; acetylsalicylic acid, OAD; oral antidiabetic drug, BUN; Blood urea nitrogen, TG; Triglyceride, TC; Total cholesterol, HDL-C; High density lipoprotein cholesterol, LDL-C; Low density lipoprotein cholesterol WAR; without atrial runs, SAR; short atrial runs, SPAFE; silent paroxysmal atrial fibrillation episode xKruskal Wallis H test; Post-hoc:Dunn-Sidak test; yExact test; $\alpha: 0.05$; * The difference is statistically significant; aDifference with WAR group is significant; bThe difference with the SARgroup is significant; cThe difference with the SPAFE group is significant 
Tablo II: Standard echocardiographic data and ECG measurements of the groups

\begin{tabular}{|c|c|c|c|c|}
\hline & WAR (n:56) & SAR (n:12) & SPAFE (n:6) & \\
\hline LVDD $^{\mathrm{x}}$,Median(Q1-Q3), mm & $47,5(45,0-50,5)$ & $47,0(45,5-49,0)$ & $47,5(44,0-52,0)$ & 0,943 \\
\hline LVSD ,Median(Q1-Q3), mm & $34,0(30,0-36,0)$ & $31,0(28,0-35,0)$ & $31,5(25,0-41,0)$ & 0,616 \\
\hline LA diameter ${ }^{x}$, mean $\pm \mathrm{SD}, \mathrm{mm}$ & $36,0(33,5-39,0)$ & $37,5(34,5-42,0)$ & $40,0(33,0-43,0)$ & 0,453 \\
\hline PAP $^{x}$,Median(Q1-Q3), mmHg & $22,0(14,0-32,5)$ & $22,5(14,0-27,5)$ & $26,0(22,0-39,0)$ & 0,441 \\
\hline LVEF$^{x}$,Median(Q1-Q3), \% & $61,0(58,0-65,0)$ & $61,0(49,5-65,0)$ & $58,5(53,0-65,0)$ & 0,678 \\
\hline $\mathrm{E}^{\mathrm{X}}$, Median(Q1-Q3), cm/s & $75,0(62,5-94,0)$ & $79,5(60,0-92,0)$ & $85,0(82,0-96,0)$ & 0,550 \\
\hline$A^{x}$, Median(Q1-Q3), cm/s & $77,0(65,5-96,5)^{c}$ & $79,5(66,0-105,5)$ & $109,0(105,0-115,0)^{a}$ & $0,043 *$ \\
\hline E/A Ratio, Median(Q1-Q3) & $0,89(0,75-1,22)$ & $0,86(0,63-1,33)$ & $0,79(0,74-0,85)$ & 0,371 \\
\hline$H R^{x}$, median(Q1-Q3), beat/m & $79,00(70,00-88,00)$ & $85,00(71,50-94,00)$ & $84,50(75,00-100,00)$ & 0,257 \\
\hline Pmax $^{x}$, median(Q1-Q3), ms & $90,00(80,00-110,00)$ & $80,00(80,00-92,50)$ & $97,50(90,00-120,00)$ & 0,123 \\
\hline Pmin ${ }^{x}$ median(Q1-Q3), ms & $65,00(55,00-70,00)$ & $60,00(45,00-67,50)$ & $55,00(40,00-60,00)$ & 0,106 \\
\hline $\mathrm{Pd}^{\mathrm{x}}$, median $(\mathrm{Q} 1-\mathrm{Q} 3), \mathrm{ms}$ & $30,00(15,00-40,00)$ & $20,00(10,00-40,00)$ & $45,00(15,00-60,00)$ & 0,392 \\
\hline fQRS, absent/present, $n(\%)$ & $35(62,50) / 21(37,50)$ & $3(25,00) / 9(75,00)$ & $0(0,00) / 6(100,00)$ & $0,002 *$ \\
\hline
\end{tabular}

LVDD; Left venricular diastolic diameter, LVSD; Left ventricular systolic diameter, LA;Left atrium, PAP; pulmonary artery pressure, LVEF; Left ventricular ejection fraction, E: Early diastolic velocity, A: Late diastolic velocity, HR; Heart rate, Pmax; Maximum P wave duration, Pmin; Minimum P wave duration, Pd; P dispersion, $f Q R S$ : Fragmented QRS, WAR; without atrial runs, SAR; short atrial runs, SPAFE; silent paroxysmal atrial fibrillation episode xKruskal Wallis H test; $\alpha: 0,05 ;$ Post-hoc:Dunn-Sidak test; *The difference is statistically significant;; aDifference with WAR group is significant; bThe difference with the SPAFE group is significant; cThe difference with the SPAFE group is significant

Tablo III: Multivariate logistic regression analysis in prediction of SAR and SPAFE

\begin{tabular}{|c|c|c|c|c|}
\hline SAR & B & Wald & $p$ & ODDS (\%95 Cl) \\
\hline LA diameter $(\mathrm{mm})$ & 0,105 & 1,558 & 0,212 & $1,111(0,942-1,311)$ \\
\hline The duration of dialysis (Month) & 0,004 & 0,240 & 0,624 & $1,004(0,988-1,021)$ \\
\hline Age (Year) & $-0,064$ & 3,575 & 0,059 & $0,938(0,877-1,002)$ \\
\hline E/A Ratio & $-2,097$ & 1,976 & 0,160 & $0,123(0,007-2,286)$ \\
\hline $\mathrm{Pd}, \mathrm{ms}$ & $-0,004$ & 0,017 & 0,896 & $0,996(0,941-1,054)$ \\
\hline fRQS morfology & $-2,889$ & 6,128 & $0,013^{*}$ & $0,056(0,006-0,548)$ \\
\hline Sex & 1,257 & 1,694 & 0,193 & $3,514(0,529-23,327)$ \\
\hline SPAFE & B & Wald & p & ODDS (\%95 Cl) \\
\hline LA diameter $(\mathrm{mm})$ & 0,088 & 0,457 & 0,499 & $1,092(0,846-1,409)$ \\
\hline The duration of dialysis (Month) & 0,001 & 0,007 & 0,935 & $1,001(0,972-1,031)$ \\
\hline Age (Year) & 0,065 & 1,288 & 0,256 & $1,067(0,954-1,194)$ \\
\hline E/A Ratio & $-3,660$ & 1,692 & 0,193 & $0,026(0,000-6,393)$ \\
\hline $\mathrm{Pd}, \mathrm{ms}$ & 0,025 & 0,485 & 0,486 & $1,025(0,956-1,098)$ \\
\hline fRQS morfology & $-21,630$ & & & \\
\hline Sex & 0,191 & 0,013 & 0,910 & $1,211(0,044-33,281)$ \\
\hline
\end{tabular}

LA; Left atrium , E: Early diastolic velocity, A: Late diastolic velocity, Pd; P dispersion, QTd; QT dispersion, fQRS: Fragmented QRS. Reference group: WAR; Multinominal logistic regression: $\alpha: 0,05$; Nagelkerke R2=0,553; * Statistically significant effect on SAR compared to reference group; ODDS: odds ratio 
The late diastolic velocitie (A) was higher in the SPAFE group than the WAR group $(p=0.043)$. Other transthoracic echocardiography findings were similar among the groups. Pmax, Pd and heart rate values were not significantly different among the groups. The frequency of fQRS morphology was significantly higher in the SAR and SPAFE groups than in the WAR group $(\mathrm{p}=0.002) \quad$ (Table II). This significance continued in the logistic regression analysis in the SAR group, and fQRS morphology was determined as an independent predictor of SAR (odds ratio $=0.056 ; 95 \%$ CI, 0.006-0.548; $\mathrm{p}=0.013$ ). However, after the multivariate analysis, the statistical significance in the SPAFE group was lost (Table III).

\section{DISCUSSION}

Our study showed that the presence of fQRS morphology in 12-lead ECG may be used as a predictor to predict SAR risk. Additionally, a statistically significant relationship was determined in our study between fQRS morphology and SPAFE.

Chronic renal failure is related to aging, coronary artery disease, congestive heart failure, hypertension, widened pulse pressure, diabetes mellitus, left ventricular hypertrophy, and valvular heart disease, all of which also cause chronic pathophysiological changes providing basis for development of $\mathrm{AF}^{1,3,16}$. Moreover, plasma electrolyte changes, abnormalities in catecholamine levels, effects of dialysate composition, sudden hemodynamic and metabolic changes caused by the hemodialysis procedure, pre-dialysis systolic blood pressure, serum albumin levels, and duration of dialysis are factors that are likely to increase the risk of $\mathrm{AF}^{17,18}$.

Hemodialysis contributes to the development of structural disorders such as diastolic dysfunction and atrial remodeling. These structural disorders are associated with the development of atrial fibrillation. Transthoracic echocardiography is a non-invasive test that can detect impairments in cardiac structure and diastolic function in the early period. The standard echocardiographic measurements were in normal ranges in all three groups. Furthermore, while the difference was not statistically significant, the LA measurement was increased in the SAR and SPAFE groups in comparison to the WAR group. The amplitude of A wave was higher in SPAFE and SAR groups than in WAR group. However, this height was statistically significant only in the SPAFE group. The E/A ratio, which is one of the indicators of diastolic dysfunction, was statistically insignificant, but it was lower in the SAR and SPAFE groups. These findings do not show marked atrial remodeling and diastolic dysfunction, but may be related to the onset of these disorders. In addition, these results are not compatible with previous studies results ${ }^{1,2,11}$. The small working volume and the patients' sinus rhythm may explain this incompatibility. Moreover, our study was a retrospective study, and there were no atrial volume and tissue doppler measurement data. For this reason, the relationship between hemodialysis-related structural changes and AF risk could not be optimally examined. It has been reported in clinical studies that the duration of HD treatment duration is an independent risk factor for the development of $\mathrm{AF}^{1,2}$. In this study, it was observed that the application time of HD treatment was longer in the SPAFE and SAR groups than in the WAR group. However, this length was statistically significant only in the SPAFE group. This showed that increased HD duration and incidence of SAR and SPAFE may be associated. Previous studies reported the AF incidence in HD patients to be $7-27 \% 1$. This broad range in incidence may have been explained by the variations in age groups, duration of renal replacement therapy, other clinical characteristics, and methodology to record AF. $\mathrm{AF}$ is seen in HD patients usually in the form of 
paroxysmal AF19. The ACC / AHA 2006 guidelines reported a threshold of 30 seconds for the diagnosis of paroxysmal AF, while SAR lasting shorter than 30 seconds may be an indicator of longer episodes ${ }^{20}$. SAR and SPAFE are a risk factor for noticeable AF that may emerge in the future6-8. In this study, episodes consisting of at least 3 irregular consecutive atrial runs were determined in 18 of the 74 patients (24\%). Among these patients, 6 (33\%) and $12(66 \%)$ respectively showed SPAFE and SAR. The Holter ECG recording time monitored in this study was 24 hours. It is also known that longer durations of recording increase the detection sensitivity of arrythmias ${ }^{21}$. The load of arrythmia in our study may have been reflected suboptimally due to the Holter ECG recording time and study volume.

Studies have shown that $\mathrm{P}$ wave abnormalities are associated with the development of AF (Pmin, Pmax, and Pd) ${ }^{22,23}$. In studies evaluating this relationship in hypertensive patients, conflicting results were found considering Pmax, but a decreased Pmin value was found to be an independent predictor of $\mathrm{AF}^{22}$. In this study, Pd and Pmax values were similar between the groups. The Pmin value was lower in the SPAFE and SAR groups, but this difference was not found to be statistically significant. The demographic characteristics of the HD population (age, comorbidities), small working volume and the effects of hemodialysis on ECGs (ECG parameters can even change before, during, or after hemodialysis) might have caused this conflicting result of our study. The abnormalities of atrial conduction may be related to atrial fibrosis. However, there are additional factors that may increase the tendency to develop AF in HD patients such as changes in volume status and electrolyte levels, generalized micro inflammatory state and metabolic derangements of uremic milieu ${ }^{24}$.

The presence of fQRS on 12-lead ECG has been related to myocardial fibrosis, ischemia, and increased inflammatory state $25-27$. Its presence in cardiovascular diseases has also been reported to be associated with sudden cardiac death, lethal ventricular arrhythmias, and increased mortality ${ }^{28,29}$. Recently, many studies have been conducted to research the relationship between fQRS morphology in ECG and development of AF. It was shown that the presence of fQRS in ECG is an independent predictor of postoperative new-onset AF in patients undergoing coronary artery bypass surgery ${ }^{10}$. Temiz et al. showed that fQRS morphology in ECG was an independent predictor of AF development in patients without structural heart disease ${ }^{11}$. Canpolat et al. also demonstrated that fQRS morphology is significantly related to left atrial scar in patients with permanent $\mathrm{AF}^{12}$. Another study conducted by Eren et al. revealed that the presence of fQRS morphology may be associated with AF recurrence following electrical cardioversion ${ }^{13}$. What is more, Yesin et al. reported that the presence of fQRS morphology in STEMI patients is a significant predictor of AF that may develop after primary coronary intervention ${ }^{14}$. The role of fQRS morphology in development of AF has not been explained clearly. Advanced ventricular fibrosis leading to an increase in left ventricular end-diastolic pressure, then increased left atrial pressure and left atrial dilatation, and finally, atrial fibrosis are the possible events providing a basis for development of AF. Additionally, acute hemodynamic and metabolic changes that are likely to occur during the hemodialysis procedure may contribute to the increased risk of AF development in HD patients. This study showed that fQRS morphology in HD patients is independently associated with SAR detected from Holter ECG recordings. Moreover, according to the findings of this study, the presence of fQRS morphology may be associated with the risk of SPAFE. Thus, in hemodialysis patients, fQRS morphology is associated with increased risk of $\mathrm{AF}$, and it may 
be useful in distinguishing patients who are under a high risk of AF. Furthermore, for investigating the predictive value of $\mathrm{fQRS}$ morphology in terms of the presence of SPAFE in hemodialysis patients, this study may provide an inspiration for prospective research designs with a broader volume and longer Holter recording durations.

\section{Limitations}

The main limitation of the study was that the study protocol was retrospective, the volume of the study was limited, and the Holter ECG recording duration was not long enough.

\section{CONCLUSION}

To the best of our knowledge, this study is the first study that investigated the relationship between fQRS morphology and AF risk in HD patients. According to the results of the study, the presence of fQRS morphology is associated with increased risk of AF development in HD patients. fQRS morphology may be an accessible, inexpensive, and non-invasive determining parameter that could be used to distinguish those with a high risk of $\mathrm{AF}$ development among HD patients and for early intervention that is important in preventing $\mathrm{AF}$ and its complications in HD patients.

Ethics Committee Approval: The research protocol in line with the Helsinki Declaration was approved by the local ethics committee (Approval Date: 05.05.2019; Protocol No:2019/09/02).

Declaration of Conflicting Interests: The authors declare that they have no conflict of interest.

Financial Disclosure: No financial support was received.

\section{REFERENCES}

1. Yıldız BS, Aladag NB, Kaptanogullari H, Sahin A. The Prevalence of Atrial Fibrillation and Related Factors Including Anthropometric, Hemodynamic and
Echocardiographic Parameters in Patients with Hemodialysis. Kosuyolu Kalp Derg 2013; 16: 229-32.

2. Zimmerman D, Sood MM, Rigatto C, et al. Systematic review and meta-analysis of incidence, prevalence and outcomes of atrial fibrillation in patients on dialysis. Nephrol Dial Transplant. 2012; 27: 3816-22.

3. Kılıçaslan F, Olgun FE. Atriyal fibrilasyon ve atriyal flutter. Helvacı ŞA, editör. Aritmili Hastaya Güncel Medikal ve Girişimsel Yaklaşımlar. 1. Baskı. Ankara: Türkiye Klinikleri. 2019; 19-31

4. Ertas F. Epidemiological approach to the atrial fibrillation patients. Dicle Medical Journal. 2013; 40: 332-9.

5. Mlodawska E, Lopatowska P, Malyszko J, et al. Atrial fibrillation in dialysis patients: is there a place for nonvitamin $\mathrm{K}$ antagonist oral anticoagulants? Int Urol Nephrol. 2018; 50: 1633-42.

6. Gül M, Özcan Çetin EH, Özeke Ö. Atrial high rate epizodlara yaklaşım. Akıllı A, Şimşek E, editörler. Kalp Pillerinde Güncelleme. 1. Baskı. Ankara: Türkiye Klinikleri. 2019; 39-49.

7. Yetim E, Topcuoglu MA, Canpolat U, et al. Nonsustained Atrial Fibrillation in Ischemic Stroke Patients and Stroke-Free Controls From the Perspective of Stroke Pathophysiology. J Am Heart Assoc. 2016; 5: e004021.

8. Larsen BS, Kumarathurai P, Falkenberg J, Nielsen OW, Sajadieh A. Excessive Atrial Ectopy and Short Atrial Runs Increase the Risk of Stroke Beyond Incident Atrial Fibrillation. J Am Coll Cardiol. 2015; 66: 232-4.

9. Altuntas E, Ciftci C. Role of P Wave Dispersion in the Prediction of Postoperative Atrial Fibrillation in the Early Period by Chronic Coronary Artery Patients Undergoing Coronary Artery Bypass Surgery without Using B Bloker Medical Treatment. Firat Med J. 2017; 22: $16-20$.

10. Çetin M, Kocaman SA, Erdoğan T, et al. Fragmented QRS may predict postoperative atrial fibrillation in patients undergoing isolated coronary artery bypass graft surgery. Anadolu Kardiyol Derg. 2012; 12: 57683.

11. Temiz A, Gazi E, Güngör O, et al. Fragmented QRS and prediction of paroxysmal atrial fibrillation episodes. Pak J Med Sci. 2014; 30: 862-. 
12. Canpolat U, Mohanty S, Trivedi C, et al. Association of fragmented QRS with left atrial scarring in patients with persistent atrial fibrillation undergoing radiofrequency catheter ablation. Heart Rhythm. 2020; 17: 203-10.

13. Eren H, Kaya Ü, Öcal L, Şenbaş A, Kalçık M. The presence of fragmented QRS may predict the recurrence of nonvalvular atrial fibrillation after successful electrical cardioversion. Ann Noninvasive Electrocardiol. 2020; 25: e12700.

14. Yesin M, Kalçılk M, Çağdaş M, et al. Fragmented QRS may predict new onset atrial fibrillation in patients with ST-segment elevation myocardial infarction. J Electrocardiol. 2018; 51: 27-32.

15. Bekar L, Katar M, Yetİm M, et al. Fragmented QRS complexes are a marker of myocardial fibrosis in hypertensive heart disease. Turk Kardiyol Dern Ars. 2016; 44: 554-60.

16. Cozzolino $M$, Mangano $M$, Stucchi $A$, et al. Cardiovascular disease in dialysis patients. Nephrol Dial Transplant. 2018; 33(suppl_3): iii28-iii34.

17. Tonelli $\mathrm{M}$, Muntner $\mathrm{P}$, Lloyd $\mathrm{A}$, et al. Risk of coronary events in people with chronic kidney disease compared with those with diabetes: a population-level cohort study. Lancet. 2012; 380: 807-14.

18. Chao TF, Liu CJ, Wang KL, et al. Incidence and prediction of ischemic stroke among atrial fibrillation patients with end-stage renal disease requiring dialysis. Heart Rhythm. 2014; 11: 1752-9.

19. Königsbrügge $O$, Posch $F$, Antlanger $M$, et al. Prevalence of Atrial Fibrillation and Antithrombotic Therapy in Hemodialysis Patients: Cross-Sectional Results of the Vienna InVestigation of AtriaL Fibrillation and Thromboembolism in Patients on HemoDIalysis (VIVALDI). PLoS One. 2017; 4; 12: e0169400.

20. Fuster V, Rydén LE, Cannom DS, et al. ACC/AHA/ESC 2006 guidelines for the management of patients with atrial fibrillation executive summary: a report of the American College of Cardiology/American Heart Association Task Force on Practice Guidelines and the European Society of Cardiology Committee for Practice Guidelines (Writing Committee to Revise the 2001 Guidelines for the Management of Patients with Arial Fibrillation). J Am Coll Cardiol. 2006; 48: 854-906.
21. Manina G, Agnelli G, Becattini C, Zingarini G, Paciaroni M. 96 hours ECG monitoring for patients with ischemic cryptogenic stroke or transient ischaemic attack. Intern Emerg Med. 2014; 9: 65-7.

22. German DM., Kabir MM., Dewland TA., Henrikson CA., Tereshchenko LG.. Atrial fibrillation predictors: Importance of the electrocardiogram. Annals of Noninvasive Electrocardiology. 2016; 21; 20-9.

23. Yıldız BŞ, Şahin A, Yıldız M. P Wave Dispersion Detected from the Surface Electrocardiography and Atrial Fibrillation. Koşuyolu Heart Journal. 2014; 17: 128-30.

24. Kalaycı B, Onan E, Paydaş S, et al. The effect of hemodialysis adequacy on ventricular repolarization in end-stage kidney disease. Turk Kardiyol Dern Ars. 2019; 47: 572-80.

25. Özkan B, Örsçelik Ö, Arslan A, Şahin EE, Özcan İT. Stabil angina pektoris ile başvuran hastalarda ciddi kroner arter darlığı ile fragmente QRS arasındaki ilişkinin araştırılması. Mersin Univ Saglık Bilim Derg. 2018; 11: 167-73.

26. Cetin M, Kocaman SA, Erdogan T, et al. The independent relationship of systemic inflammation with fragmented QRS complexes in patients with acute coronary syndromes. Korean Circ J. 2012; 42: 449-57.

27. Eyüboğlu M, Akdeniz B. Fragmente QRS kompleksleri koroner anjiyografi uygulanan stabil koroner arter hastalarında daha yüksek Gensini skorunu öngördürmektedir. Ege Tıp Dergisi. 2018; 57: 71-4.

28. Bekler A, Gazi E, Erbağ G, et al. Relationship between presence of fragmented QRS on 12-lead electrocardiogram on admission and long-term mortality in patients with non-ST elevated myocardial infarctionTürk Kardiyol Dern Arş - Arch Turk Soc Cardiol. 2014; 42: 726-32.

29. Kocaman SA, Cetin M, Kirıs T, et al. The importance of fragmented QRS complexes in prediction of myocardial infarction and reperfusion parameters in patients undergoing primary percutaneous coronary intervention. Türk Kardiyol Dern Arş. 2012; 40: 21322. 